around the library, operate by way of touch screen technology.

The five-floor building was designed by Evans Woollen, a nationally recognized architect based in Indianapolis. The Grainger Foundation of Skokie, Illinois, donated $\$ 18.7$ million to erect the library. The gift honors W. W. Grainger, a U. of I. College of Engineering Class of 1919 alumnus and founder of W. W. Grainger Inc.

\section{ACRL collects information literacy data}

This fall ACRL was approached by two of the regional accrediting agencies-Middle States Association and Western Association of Schools and Colleges - to enter a cooperative research project for the purpose of collecting data on existing information literacy programs in higher education institutions across the U.S. The ACRL Executive Committee approved a proposal at its fall meeting to implement the project. At the request of the accrediting agencies the mailings went to their campus contacts (usually provosts and deans) with instructions that the instruments were to be distributed on campuses to the units best suited to respond. In some cases the campus will identify the library as the appropriate unit to respond to the survey. As this study develops, further reports will be published in CERL News and the ACRL Forum.

\section{STS discussions at Midwinter}

The ACRL Science and Technology Section invites you to attend the following lively discussion groups at the ALA Midwinter Meeting in Philadelphia. STS General Discussion Group meeting, Sunday, February 5, 8:30-11:00 a.m. Topic: "Integrating Internet Resources into Sci-Tech Libraries." STS Science Databases Discussion Group, Saturday, February 4, 2:00—4:00 p.m. Topic: "Electronic Pre-print Databases and the World Wide Web."

\section{Getting the 1992 library data}

The data on 54 variables in academic libraries in the United States reported to the National Center for Education Statistics (NCES) and discussed by Mary Jo Lynch in the November 1994 CERL News are now available to the public. To obtain a copy of Academic Libraries: 1992 (NCES95-031) for \$3.75 from the Government Printing Office (stock \# (S/W) 065-000-007177) call (202) 512-1800.

\title{
Overdue notices: Cutting costs and saving time
}

Many libraries in these tough economic times have had to reduce staff, services, and acquisitions. Given moderate downsizing, examination of some long-held procedures may free resources that can be used to sustain other, more desirable services. Evaluation of procedures may also result in unexpected benefits, such as those from an evaluation of postage costs and overdue notices at the University of Oklahoma.

The existing overdue notice schedule included three overdue notices and a bill. The notices were spaced at 7,21 , and 45 days past due. Billing occurred at 90 days. An examination of other libraries' procedures revealed many libraries billed earlier in the cycle, and past research suggested a shorter billing interval would reduce overdues. Further considerations included an analysis of the number of items turned in after each overdue notice was sent.

The following changes were made: a) the second notice was reformatted and labeled "FINAL NOTICE" and the wording of the no- tice clearly pointed out the impending financial penalties; b) the third notice was eliminated; c) the libraries eliminated the bill and relied on the University Bursar to notify patrons of billing costs; and d) mailing intervals were shortened. The second and final notice was mailed at 15 days and billing was forwarded to the University Bursar at 30 days.

\section{Results}

The change reduced the number of notices mailed by approximately $20 \%$. This amounted to a savings of about $\$ 800$ in postage for the first seven months. The most important result of the change, though, was the freeing of billing staff from notice-related duties. As a result, ten hours of staff time/week were reallocated to interlibrary loan operations. Shortening of the notice and billing cycle also improved book return rates among library patrons, as the total number of items outstanding at 30 days fell by two-thirds. - Steve Horn and Pat Weaver-Meyers, University of Oklahoma Libraries, Norman 